\title{
Primary health care tasks in implementing the main operations of public health
}

\author{
PIOTR ZBIGNIEW TYSZKOA, D, G, ANETA NITSCH-OSUCH'A, B, D , MAGDALENA MIŃKO \\ KRZYSZTOF KANECKIA, D-F
}

Department of Health Care, Medical University of Warsaw

A - Study Design, B - Data Collection, C - Statistical Analysis, D - Data Interpretation, E - Manuscript Preparation,

$\mathbf{F}$ - Literature Search, $\mathbf{G}$ - Funds Collection

Summary Public health and primary health care are complementary strategies for sustaining the health of a society. There are many analyses in the literature on the subject that deal with the possibility of mutual support between public health and primary health care. There reports from many countries include studies of scientific institutions, presentations of specific solutions used by health protection administrations and self-government bodies, programs of study, and courses. However, this issue is rarely raised in Poland. The aim of this article is to present an up-to-date list of public health operations and to where there is room for primary health care activities. A binding list of public health operations was defined by the World Health Organisation (WHO) in 2012 under the name of Essential Public Health Operations (EPHOs). In order to define public health operations more precisely in this article, a questionnaire self-assessment tool for the evaluation of essential public health operations in the WHO European Region was used. Primary health care plays a significant role in the performance of public health operations (EPHOs), whereas the public health operations connected with health protection (EPHO 3), health promotion (EPHO 4) and disease prevention (EPHO 5), are mostly attributed to primary health care. Primary health care provides the information necessary for the performance of public health operations in the field of monitoring population health and well-being - in particular infectious and chronic diseases (EPHO 1), and for health care management and improvement of health care quality (EPHO 6). Key words: primary health care, family medicine, public health, public health operations.

Fam Med Prim Care Rev 2016; 18(3): 394-397

\section{Background}

The simultaneous entry of the search terms primary health care and public health into a search engine gives about 270 million results. This huge number of results implies that the dependency between these two seemingly distant health-influencing strategies is seen, analyzed and used in practice. Since the Alma-Ata conference, primary health care has been defined as essential health care based on practical, scientifically sound, and socially acceptable methods and technology, made universally accessible to individuals and families in the community through their full participation and at a cost that the community and country can afford to maintain at every stage of its development, in the spirit of self-reliance and self-determination [1]. Primary health care can be characterized by the following features:

- $\quad$ it is based on public health experience;

- it addresses the main health problems in the community and provides promotive, preventive, curative, and rehabilitative services;

- it includes education on the most common health problems and methods of combating them, promotion of the food supply and proper nutrition, an adequate supply of safe water and basic sanitation, maternal and child health care, and immunization against major infectious diseases;

- it involves, besides the health sector, all other sectors in a coordinated effort for health.

The characteristics of family medicine - which is considered the optimal form of primary health care - include factors that are important from the point of view of public health, such as:
- $\quad$ open and unlimited access to users, dealing with all health problems regardless of age, sex, or any other characteristic of the person concerned;

- consideration in the decision-making process, of epidemiological indicators, such as the prevalence and incidence of illness in the community;

- $\quad$ promotion of health and well-being both by appropriate return and effective intervention;

- the presence of specific responsibilities for the health of the community [2].

Public health is the science and art of preventing disease, prolonging life, and promoting physical health and efficiency through organized community efforts for sanitation of the environment, control of community infections, education of the individual in principles and personal hygiene, organization of medical and nursing services for early diagnosis and preventive treatment of disease, and development of the social machinery to ensure every individual a standard of living adequate for the maintenance of health. The author of this definition from 1920 was Yale University Professor C.E. Winslow [3].

An analysis of the definitions presented above shows similarities between the goals and operating methods (to some extent) and a significant difference in the scales of operation. To simplify the issue, suffice it to say that a strategic goal of public health is to exert a positive influence on the health of rather large communities (broadly understood); whereas, a realistic goal of primary health care is to exert a positive influence on individual health and the health of small communities, including local communities.

An analysis of websites that jointly present the issue of public health and primary health care shows that they consist of articles dedicated to building relations between 
these two health-influencing strategies, creating models of practical cooperation and presenting the experience gained from practical activities. There are also websites from administrative bodies for health protection, local government institutions, research institutes, and higher education institutions, as well as websites that present programs of studies and courses on public health and primary health care [4-8]. It can be observed that most attention is devoted to the issue of the relationship between primary health care and public health in the United States, whereas this is issue is rarely raised in Poland. One example of Polish research into the topic is a study published in the journal Lekarz Rodzinny in 2005 [9]. Another example is a 2014 issue of Public Health Management dedicated to family medicine [10].

A closer analysis of the results of the joint search for primary health care and public health reveals a division of the results into two groups. The first group refers to the use of the scope and methods of the operations of primary health care $(\mathrm{PHC})$ for the performance of public health operations. The other group refers to the opposite way of thinking - that is, the use of the resources, tools, and mechanisms of public health for the fulfillment of targets and tasks of primary health care (Fig. 1).

The aim of this article is to present an up-to-date list of public health operations and to indicate those where there is room for primary health care, in line with the declared objectives of this form of care, and taking into account the solutions employed in Poland.

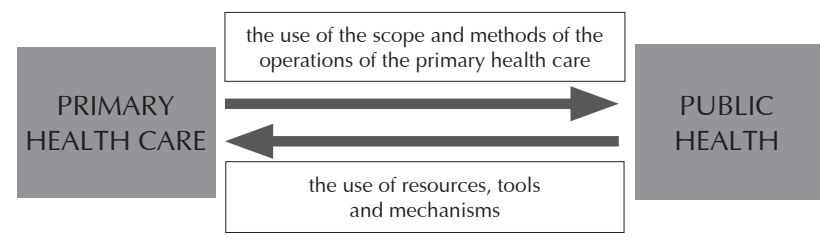

Figure 1. Study of the interactions between public health and primary health care

\section{Public health operations}

In 2012, the WHO Regional Committee for Europe accepted The European Action Plan (EAP) for Strengthening Public Health Services and Capacity as the basis for the Health 2020 policy [11]. One of key elements of this plan is the proposal of ten essential horizontal activities (operations) in the field of public health, referred to as Essential Public Health Operations (EPHOs) [zdw2020], which are divided into two main groups (Fig. 2).
The first group is described as "the core" and consists of essential activities that require specialist knowledge and abilities. These are the operations from EPHO 1 to EPHO 5. Within the framework of this division, the following subgroups are distinguished under public health care: health protection, health promotion, disease prevention (EPHO 3, $\mathrm{EPHO} 4, \mathrm{EPHO}$ 5), and a subgroup of intelligence activities based on monitoring, surveillance, and scientific research (EPHO 1, EPHO 2, and EPHO 10).

The other group consists of Enabler Operations from EPHO 6 to EPHO 10 (Fig. 2).

WHO considers all these operations to be available, effective, and of the highest quality.

A detailed list of particular activities included in EPHOs is defined in a questionnaire used by WHO for research into the performance of public health operations in different countries, including Poland [13]. The main components of ten public health operations, according to the Self-assessment tool for the evaluation of essential public health operations in the WHO European Region are presented in Table 1.

\section{Primary health care activities that support the implementation of public health operations}

The most obvious place to seek the role of primary health care in the implementation of public health operations is EPHO 5: Disease prevention, including early detection of illness. EPHO 5 includes, among other elements:

- primary prevention, including the implementation of immunization programs and other prevention programs, maternal and child health care;

- $\quad$ secondary prevention, including early detection of pathologies - as part of daily practice, as well as through participation in organized programs;

- tertiary prevention, including chronic pain management, rehabilitation, palliative and end-of-life care, patient support groups;

- cooperation in the area of social support.

Implementation of these activities within the framework of primary health care is a prerequisite for the performance of an operation which is the main concern of public health. It is worth noting that the tasks contained in EPHO 5 are assigned to primary health care, both in a general sense, as rules, and in the contractual sense, as the tasks of PHC doctors, especially family medicine doctors.

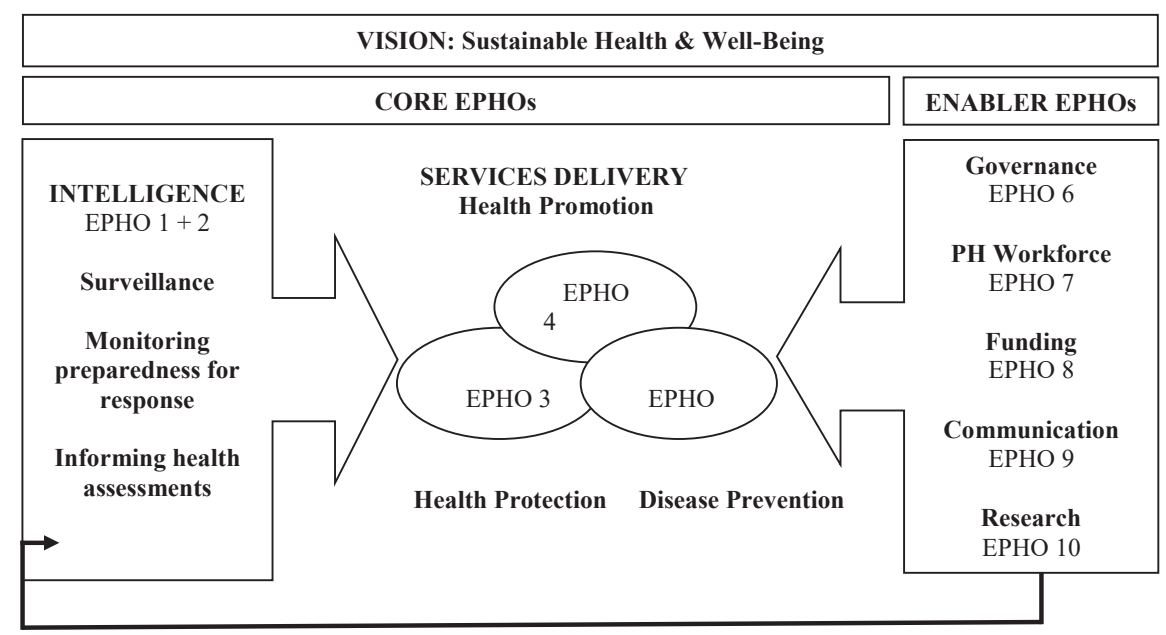

Figure 2. Clustering of Essential Public Health Operations (EPHOs) to deliver public health services. Source: [12]. 


\begin{tabular}{|c|c|}
\hline Public health operations according to EPHO & $\begin{array}{l}\text { Main activities } \\
\text { (number of specific activities in brackets) }\end{array}$ \\
\hline $\begin{array}{l}\text { EPHO 1: Surveillance of population health } \\
\text { and well-being }\end{array}$ & $\begin{array}{l}\text { 1.A. Health data sources and tools (4) } \\
\text { 1.B. Surveillance of population health and disease programs (17) } \\
\text { 1.C. Surveillance of health system performance (5) } \\
\text { 1.D. Data integration, analysis and reporting (5) }\end{array}$ \\
\hline $\begin{array}{l}\text { EPHO 2: Monitoring and response to health } \\
\text { hazards and emergencies }\end{array}$ & $\begin{array}{l}\text { 2.A. Identification and monitoring of health hazards (4) } \\
\text { 2.B. Preparedness and response to public health emergencies (9) } \\
\text { 2.C. Implementation of international health regulations (IHRs) (6) }\end{array}$ \\
\hline $\begin{array}{l}\text { EPHO 3: Health protection, including envi- } \\
\text { ronmental, occupational and food safety and } \\
\text { others }\end{array}$ & $\begin{array}{l}\text { 3A. Environmental health protection (7) } \\
\text { 3.B. Occupational health protection ( } 7 \text { ) } \\
\text { 3.C. Food safety (4) } \\
\text { 3.D. Patient safety (6) } \\
\text { 3.E. Road safety (4) } \\
\text { 3.F. Consumer product safety (3) }\end{array}$ \\
\hline $\begin{array}{l}\text { EPHO 4: Health promotion including action } \\
\text { to address social determinants and health } \\
\text { inequity }\end{array}$ & $\begin{array}{l}\text { 4.A. Intersectoral and interdisciplinary capacity (3) } \\
\text { 4.B. Addressing behavioral, social and environmental determinants of health } \\
\text { through a whole-of-government, whole-of-society approach (10) }\end{array}$ \\
\hline $\begin{array}{l}\text { EPHO 5: Disease prevention, including early } \\
\text { detection of illness }\end{array}$ & $\begin{array}{l}\text { 5.A. Primary Prevention (6) } \\
\text { 5.B. Secondary prevention (3) } \\
\text { 5.C. Tertiary/quaternary prevention (3) } \\
\text { 5.D. Social support (2) }\end{array}$ \\
\hline EPHO 6: Assuring governance for health & $\begin{array}{l}\text { 6.A. Leadership for a whole-of-government and whole-of-society approach to } \\
\text { health and well-being (2) } \\
\text { 6.B. Health policy cycle (5) } \\
\text { 6.C. Regulation and control (see also relevant sections in EPHO 3) (4) }\end{array}$ \\
\hline $\begin{array}{l}\text { EPHO 7: Assuring a competent public health } \\
\text { workforce }\end{array}$ & $\begin{array}{l}\text { 7.A. Human resources development cycle (4) } \\
\text { 7. B. Human Resources Management (4) } \\
\text { 7.C. Public health education ( } 3 \text { ) } \\
\text { 7.D. Governance of public health human resources (2) }\end{array}$ \\
\hline $\begin{array}{l}\text { EPHO 8: Assuring organizational structures } \\
\text { and financing }\end{array}$ & $\begin{array}{l}\text { 8.A. Ensure appropriate organizational structures to deliver EPHOs (7) } \\
\text { 8.B. Financing public health services (3) }\end{array}$ \\
\hline $\begin{array}{l}\text { EPHO 9: Information, communication and } \\
\text { social mobilization for health }\end{array}$ & $\begin{array}{l}\text { 9.A. Strategic and systematic approach to public health communication (5) } \\
\text { 9.B. Information and communication technology (ICT) for health (1) }\end{array}$ \\
\hline $\begin{array}{l}\text { EPHO 10: Advancing public health research } \\
\text { to inform policy and practice }\end{array}$ & $\begin{array}{l}\text { 10.A. Setting a national research agenda (2) } \\
\text { 10.B. Capacity-building (5) } \\
\text { 10.C. Coordination of research activities (1) } \\
\text { 10.D. Dissemination and knowledge-brokering (3) }\end{array}$ \\
\hline
\end{tabular}

Another place where primary health care tasks are to be found is EPHO 3. The share of primary health care in health protection, including environmental safety, results from the principle of taking responsibility for the health of the local community, which is clearly emphasized in family medicine. In Poland, it is the duty of those responsible for primary health care to recognize health determinants and to identify local needs. Nurses play a special role in this regard [14].

An important activity of $\mathrm{PHC}$ is to ensure patient safety. In public health, this recommendation refers to the entire health care system, but it also must be observed in PHC, where a patient most frequently comes into contact with the health care system. In Poland, there are nearly 160 million appointments for medical advice annually [15].

The essence of PHC activities related to $\mathrm{EPHO} 4$ is to participate in health promotion. Participation in health promotion is listed in the PHC principles as the obligation of health education. It also results from the need to include behavioral, social, and environmental determinants of health through a whole-of-government, whole-of-society approach. The areas indicated for health promotion include, among others: tobacco control, alcohol control, physical activity, substance abuse, mental health, domestic violence and violence against children and women, social determinants of health.
All the measures discussed above are relevant to public health and represent, to a large extent, the essence of primary health care. However, apart from those discussed previously, another group of activities that are indirectly related to the performance of health care can be indicated.

Performance of public health operations, including EPHO 1 (surveillance of population health and well-being) and EPHO 2 (monitoring and response to health hazards and emergencies), is conditioned by the provision of necessary data from PHC - such as data concerning the suspicion of infectious diseases and occupational diseases, the diagnosis of infectious diseases, the incidence of chronic diseases, and so on. The obligation to communicate such data to the appropriate authorities is regulated in Poland by statutory law - for example, the case of infectious diseases is dealt with by the Act for the Prevention and Control of Infections and Infectious Diseases in Humans [16]. A number of primary health care duties related to the implementation of the operations described above result from the Research Program for Public Statistics carried out on an annual basis, but other sources also exist [17]. This research constitutes a source of information about the state of health of the population, including the number of outpatients treated for selected diseases, and the number of patients treated for chronic diseases by PHC doctors and specialists. Such data is used at different levels of health care management and is very carefully 
analyzed at the voivodeship level to track changes in the incidence of selected diseases - including social diseases like tuberculosis, sexually transmitted diseases, and others. Separate reporting that is significant for public health in Poland deals with the execution of contracts between service providers and the National Health Fund.

Last but not least, one public health operation which might be supported by primary health care is EPHO 6. This operation indicates the necessity of universal access to primary care, in line with the Declaration of Alma Ata, and raises the issue of participation in ensuring health care efficiency features, such as effectiveness, efficiency, accessibility, acceptability, quality and equity.

\section{Summary}

Primary health care plays an important role in the implementation of public health operations, including health protection, health promotion, and disease prevention. It is also essential for operations relating to the monitoring of population health and well-being, as well as for the operations which assure governance for health. In Poland, there have been no studies on the essence of cooperation between the institutions of public health and primary health care or on the possibilities of developing such cooperation for the improvement of the health status of the population.

Source of funding: This work was funded by the statutory activity of Medical University of Warsaw.

Conflict of interest: The authors declare no conflict of interests.

\section{References}

1. Declaration of Alma-Ata. International Conference on Primary Health Care, Alma-Ata, USSR, 6-12 September 1978 [cited 01.03.2016]. Avaible from URL: http://www.searo.who.int/LinkFiles/Health_Systems_declaration_almaata.pdf.

2. WONCA. The European Definition of General Practice/Family Medicine. Wonca Europe 2011 Edition [cited 22.04.2016]. Available from URL: http://www.woncaeurope.org/gp-definitions.

3. Winslow CE. The Untitled Fields of Public Health. Science 1920; 51(1306): 23-33.

4. Levesque JF, Breton M, Senn N, et al. The Interaction of Public Health and Primary Care: Functional Roles and Organizational Models that Bridge Individual and Population Perspectives. Public Health Rev 2013; 35(1): 1.

5. American Academy of Family Physicians Integration of Primary Care and Public Health (Position Paper) 2014 [cited 29.03.2016]. Avaible from URL: http://www.aafp.org/about/policies/all/integprimarycareandpublichealth.html.

6. Primary Care and Public Health: Exploring Integration to Improve Population Health. Institute of Medicine. Washington, DC: The National Academies Press; 2012.

7. Starfield B. Public Health and Primary Care: Challenges and Opportunities for Partnership. Ethnicity Disease 2003; 13: 12-13.

8. Public Health in a Primary Health Care Setting. 2003 April [cited 30.03.2016]. Avaible from URL: http: //www.moh.govt.nz/ primaryhealthcare.

9. Tyszko P. Medycyna rodzinna a zdrowie publiczne. Lek Rodz 2005; 9(97): 864-870.

10. Kurpas D. Zadania podstawowej opieki zdrowotnej w zakresie opieki nad pacjentami z chorobami przewlekłymi. Zdr Publ Zarz 2014; 12(4): 301-308.

11. The European Action Plan (EAP) for Strenghtening Public Health Services and Capacity [cited 01.03.2016]. Available from URL: http://www.euro.who.int/_data/assets/pdf file/0005/171770/RC62wd12rev1-Eng.pdf?ua=1.

12. Strengthening public health services and capacity: an action plan for Europe [cited 30.03.2016]. Available from URL: http:// www.euro.who.int/_data/assets/pdf_file/0007/172762/Strengthening-public-health-services-and-capacity-an-action-plan-forEurope-Eng.pdf.

13. Self-assessment tool for the evaluation of essential public health operations in the WHO European Region; WHO 2015 [cited 01.03.2016]. Available from URL: http://www.euro.who.int/_data/assets/pdf_file/0018/281700/Self-assessment-tool-evaluation-essential-public-health-operations.pdf.

14. Rozporządzenie Ministra Zdrowia z dnia 20 października 2005 r. w sprawie zakresu zadań lekarza, pielęgniarki i położnej podstawowej opieki zdrowotnej (Dz.U. z 2005 r., nr 214, poz. 1816).

15. Rocznik statystyczny RP 2015. Warszawa: GUS 2015: 379 (tab. 5(277)).

16. Ustawa z dnia 5 grudnia 2008 r. o zapobieganiu oraz zwalczaniu zakażeń i chorób zakaźnych u ludzi (Dz.U. z 2008 r., nr 234, poz. 1570).

17. Program badań statystycznych statystyki publicznej na rok 2016. Załącznik do Rozporządzenia Rady Ministrów z dnia 21 lipca 2015 r. w sprawie programu badań statystycznych statystyki publicznej na rok 2016 (Dz.U. z 2015 r., poz. 1304).

Address for correspondence:

Piotr Tyszko, MD, PhD

Katedra Medycyny Społecznej WUM

ul. Oczki 3

02-007 Warszawa

Polska

Tel.: +48 22 621-52-56

E-mail: ptyszko@wum.edu.pl

Received: 31.03.2016

Revised: 12.04.2016

Accepted: 26.04.2016 